\title{
Efektivitas Teknik Restrukturisasi Kognitif dalam Konseling Individual untuk Mereduksi Perilaku Merokok
}

\author{
Yusadri $^{1}$, Alfi Rahmi ${ }^{1 *}$, Intan Sari ${ }^{1}$ \\ ${ }^{1}$ Institut Agama Islam Negeri Bukittinggi, Indonesia. \\ *Korespondensi: alfirahmi@gmail.com
}

\begin{abstract}
The aim of this research is to find out the effectiveness of cognitive restructuring techniques in individual counseling to reduce the smoking behavior of students in SMA N 1 Batipuh. This research is a Pre Experiment One Group Pretest Posttest Design model. The population is students of class XI IPA and $X I$ IPS as many as 20 people, while the study sample is students of class XI IPA as many as 5 people and are indicated to have smoking behavior based on non rondom sampling techniques and recommendations from BK teachers. Data collection instruments are in this study a Likert scale. Data analysis techniques using non-parametric statistical tests using Wilcoxon rank test, hypothesis testing using Statistical Product and Service Solution (SPSS) version 20. The results of research that have been known from the results of the $Z$ (Wilcoxon) test values show the difference between the pretest and posttest scores. From the Wilcoxon test calculation results obtained a significance value of Sig $p$ value of-2.032. Based on the applicable provisions, it is known that the Wilcoxon Sig p-value test result is $0.042<\alpha(\alpha=0.05)$ which means that Ha is accepted and Ho is rejected. From the calculation results of the Wilcoxon test it can be concluded that individual counseling using cognitive restructuring techniques can reduce student smoking behavior.
\end{abstract}

Keywords: Cognitive Restructuring Techniques, Reduce; Smoking Behavior.

\begin{abstract}
Abstrak
Tujuan yang akan dicapai dalam penelitian ini adalah untuk mengetahui efektivitas teknik restrukturisasi kognitif dalam konseling individual untuk mereduksi perilaku merokok siswa di SMA N 1 Batipuh. Penelitian ini adalah penelitian Pre Eksperimen model One Group Pretest Posttest Design. Populasi adalah siwa kelas XI IPA dan XI IPS sebanyak 20 orang, sedangkan sampel penelitian adalah siswa kelas XI IPA sebanyak 5 orang serta yang terindikasi memiliki perilaku merokok berdasarkan teknik non rondom sampling dan rekomendasi dari guru BK. Instrumen pengumpulan data adalah dalam penelitian ini skala dengan skala likert. Teknik analisis data menggunakan uji statistik non parametrik menggunakan Wilcoxon rank test, uji hipotesis menggunakan Statistical Product and Service Solution (SPSS) versi 20. Hasil penelitian yang telah diketahui dari hasil nilai uji $Z$ (Wilcoxon) menunjukkan perbedaan antara nilai pretest dan posttest. Dari hasil perhitungan uji Wilcoxon diperoleh nilai signifikansi Sig $p$-value sebesar-2,032. Berdasarkan ketentuan yang berlaku, diketahui hasil uji Wilcoxon Sig $p$-value sebesar $0,042<\alpha(\alpha=0,05)$ yang artinya Ha diterima dan Ho ditolak. Dari hasil perhitungan uji Wilcoxon dapat disimpulkan bahwa konseling individual menggunakan teknik restrukturisasi kognitif dapat mereduksi perilaku merokok siswa.
\end{abstract}

Kata Kunci: Teknik Restrukturisasi Kognitif; Konseling Individual; Mereduksi; Perilaku Merokok; Siswa.

How To Cite : Yusadri, Y., Rahmi, A., \& Sari, I. (2020). Efektivitas Teknik Restrukturisasi Kognitif dalam Konseling Individual untuk Mereduksi Perilaku Merokok. Biblio Couns: Jurnal Kajian Konseling dan Pendidikan, 3(2), 56-66. 


\section{PENDAHULUAN}

Pendidikan merupakan suatu elemen yang sangat penting dalam hidup manusia yang dapat mempengaruhi kecerdasan intelektual, emosional dan spiritual. Dimana ketiga kecerdasan tersebut saling mempengaruhi dalam aspek kepribadian manusia serta ketiga kecerdasan tersebut juga diperoleh salah satunya melalui dunia pendidikan. Pendidikan itu merupakan suatu energi yang dapat mempengaruhi aspek kepribadian pada diri manusia dengan tujuan memuliakan manusia itu sendiri sebagai ciptaan Allah yang sempurna dan sebaik-baiknya bentuk sebagaimana firman Allah dalam surat At-tin:4 yang artinya "Sesungguhnya kami telah menciptakan manusia dalam bentuk yang sebaik-baiknya" (Departemen Agama, 2004).

Pendidikan yang membentuk kepribadian dan karakter berawal dari penegakkan etika dan moral daam diri, keluarga, sekolah dan masyarakat. Dalam pilar yang dikemukakan oleh UNESCO dimulai dari belajar untuk mengetahui, belajar untuk melakukan, belajar untuk menjadi sesuatu dan belajar untuk hidup bersama (Sesmiarni, 2015).

Sehubungan dengan itu, Azra dalam Iswantir merumuskan bahwa pendidikan adalah suatu proses di mana suatu bangsa mempersiapkan generasi mudanya untuk menjalankan kehidupan dan untuk memenuhi tujuan hidup secara efektif dan efisien. la menegaskan, bahwa pendidikan lebih dari pada sekedar pengajaran. Pendidikan adalah suatu proses di mana suatu bangsa atau Negara membina dan mengembangkan kesadaran diri diantara individu-individu_(Iswantir, 2017).

Pendidikan itu merupakan suatu pembelajaran yang diberikan oleh seseorang ahli (Guru) yang membantu individu dari yang tidak tau menjadi tau, dari yang tidak pandai menjadi pandai, dari yang tidak memahami menjadi paham. Pendidikan pada dasarnya adalah usaha sadar untuk menumbuh kembangkan potensi sumber daya manusia peserta didik dengan cara mendorong dan memfasilitasi kegiatan belajar mereka.

Secara detail, dalam Undang-Undang RI Nomor 20 tahun 2003 tentang Sistem pendidikan Nasional bab 1 Pasal 1 pendidikan didefenisikan sebagai usaha sadar dan terencana untuk mewujudkan suasana belajar dan proses belajar agar peserta didik secara aktif mengembangkan potensi dirinya untuk memiliki kekuatan spiritual keagamaan, pengendalian diri, kepribadian, kecerdasan, akhlak mulia, serta keterampilan yang diperlukan dirinya,masyarakat, bangsa dan negara (SISDIKNAS, 2003).

Proses pendidikan sendiri juga diperlukan adanya bimbingan dan konseling di dalamnya yang nantinya akan dilaksanakan oleh guru BK, dimana bimbingan dan konseling sendiri merupakan proses bantuan atau pertolongan yang diberikan oleh pembimbing atau konselor kepada individu atau klien melalui pertemuan tatap muka atau hubungan timbal balik antara keduanya, agar klien memiliki kemampuan atau kecakapan melihat dan menemukan masalahnya serta mampu memecahkan masalahnya sendiri, atau proses pemberian bantuan atau pertolongan yang sistematis dari pembimbing atau konselor kepada klien atau siswa melalui pertemuan tatap muka atau hubungan timbal balik antara keduanya untuk mengungkapkan masalah klien sehingga klien mampu melihat masalah sendiri, mampu menerima dirinya sendiri sesuai dengan potensinya, dan mampu memecahkan sendiri masalah yang dihadapinya (Tohirin, 2011). Bimbingan dan konseling sendiri pada dasarnya bertujuan untuk memandirikan klien dalam hal ini membantu klien menemukan solusi dari 
setiap permasalahan dalam pengembangan pribadi, belajar, sosial, keluarga, karir, dan kehidupan beragama.

Tujuan dari bimbingan dan konseling sendiri agar nantinya klien dapat merencanakan kegiatan penyesuaian studi dalam hal pengembangan karir serta kehidupannya dimasa yang akan datang, mengembangkan seluruh potensi dan kekuatan yang dimilikinya seoptimal mungkin, menyesuaikan diri dengan lingkungan pendidikan, lingkungan masyarakat dan lingkungan kerja, mengatasi hambatan dan kesulitan yang dihadapi dalam studi, penyesuaian dalam lingkungan pendidikan, masyarakat maupun lingkungan kerja. Hal ini juga dilakukan untuk membantu memandirikan peserta didik terlebih lagi dalam suasana perkembangan yang dinilai menemui banyak masalah, diantaranya masalah siswa merokok, yang mana merokok dikalangan pelajar saat ini tidak lagi menjadi hal yang baru tapi sudah menjadi topik disetiap jenjang pendidikan terlebih lagi pada sekolah menengah, bahkan pelajar sekarang sudah tidak lagi menghiraukan peringatan-peringatan yang diberikan (Sutirna, 2013).

Dewasa ini kegiatan merokok sering dilakukan remaja dimulai dari remaja yang duduk dibangku Sekolah Menengah Pertama (SMP) bahkan mungkin sebelumnya sudah mencoba merokok. Pada Saat anak mulai duduk di bangku SMP anak sudah banyak yang merokok, ini terlihat pada anak yang berkumpul - kumpul dengan temannya dipinggir jalan maupun ditempat-tempat umum lainnya. Menurut mereka merokok merupakan lambang pergaulan. Hampir semua invdividu merokok dengan alasan yang sedikit sekali kaitannnya dengan kenikmatan, dalam pikiran remaja, rokok merupakan lambang kedewasaan (Prasetya, 2017).

Dilihat dari perkembangan psikologi siswa yang duduk dibangku pendidikan dapat digolongkan pada masa remaja, masa remaja sering disebut juga dengan negatif fase dengan gejala pokok menyendiri, kurang kemauan, perubahan minat dan pola perilaku, dengan demikian dekatnya usia kematangan yang sah, para remaja merasa gelisah untuk meningkatkan diri pada perilaku yang dihubungkan dengan merokok, minuman keras dan mengkonsumsi obat-obat terlarang, mereka menganggap bahwa perilaku mereka mencerminkan citra yang mereka inginkan.

Menurut Elizabert B Hurlock merokok sering kali dimulai di sekolah menengah pertama, bahkan sebelumnya. Pada anak duduk di sekolah menengah atas, merokok merupakan kegiatan yang meluas dalam daerah-daerah terlarang, seperti di halaman sekolah (Hurlock, 1980). Perilaku merokok merupakan aktivitas menghisap rokok dengan menggunakan pipa rokok dan mengeluarkan asap rokok melalui mulut, reaksi yang dapat diamati secara umum dan objektif dan dapat dilakukan orang dewasa, remaja bahkan anak-anak usia sekolah dasar. Merokok sudah menjadi kebutuhannya bagi para pengguna rokok. Merokok di kalangan remaja merupakan suatu ajang atau pencarian jati diri, dalam hal ini remaja melakukan kebiasaan merokok sebagai simbol kejantanan, merokok dapat mengurangi kecemasan bahkan menjadikan macho apabila melakukan aktivitas dan bahkan menjadikan kebiasaan ini. Awal mulanya dengan mencoba-coba rokok karena tawaran dari teman sebaya, bahkan melihat sendiri orang tua, teman sebaya, pengaruh iklan sehigga menimbulkan motif pribadi untuk merokok. Perilaku merokok pada pelajarpun merupakan fenomena sosial yang sudah amat sangat lumrah ditemui dilingkungan sekolah.

Dimana orang merokok dapat dilihat dari ciri-ciri umumnya yaitu : Pipi perokok terlihat kempot, kulit jadi hitam, mata merah, kuku membiru, bibir dan gusi menjadi hitam, mudah terserang penyakit batuk, nafasnya bau, nafas seorang perokok tidak kuat dan tidak panjang. Salah satu dampak dari rokok itu ternyata bagi individu sangat berbahaya sekali seperti: hilangnya rasa ingin tahu, semangat untuk belajar dan berbagai hal positif pada diri kita hilang ketika kita menjadi seseorang yang perokok termasuk dalam pengetahuan dan kognitif kita menjadi berkurang. Untuk itu dibutuhkan konseling kognitif perilaku, pelopor dari psikoterapis 
CBT seperti Albert Ellis (psikolog) dan Aaron Beck (psikiater) yang ditekankan peran memediasi faktor kognitif. Mereka menemukan bahwa pemikiran atau interpretasi spesifik dari stimulus memengaruhi respons perilaku orang tersebut. Pendekatan CBT memusatkan perhatian pada proses berfikir klien yang berhubungan dengan kesulitan emosionaldan psikologi klien. Pendekatan ini akan berupaya membantu klien mengubah pikiran-pikiran atau pernyataan diri negative dan keyakinan-keyakinan pasien yang tidak rasional. Jadi fokus teori ini adalah mengganti cara-cara berfikir yang tidak logis menjadi logis. Meinchenbauum menyataka pendekatan CBT merupaka pendekatan terapeutik yang memodifikasi pikiran, asumsi, dan sikap yang ada pada individu (Lubis, 2009). Pusat kognitif terapi adalah restrukturisasi kognitif (mengubah pikiran dan interpretasi seseorang). Restrukturisasi kognitif melibatkan lembut membantu klien menjadi lebih fleksibel dalam mereka berpikir dan tidak mengunci interpretasi "pertama" atau pemahaman tentang apa itu terjadi di sekitar mereka atau di dalam tubuh mereka (Sochting, 2014).

Restrukturisasi kognitif sendiri yaitu suatu teknik yang menghasilkan kebiasaan baru pada konseli dalam berfikir, merasa dan bertindak dengan cara mengidentifikasi kebiasaan bermasalah, memberi label pada kebiasaan tersebut, menggantikan tanggapan atau persepsi diri yang negatif atau irrasional menjadi lebih rasional atau realistis. Dalam teknik restrukturisasi kognitif ini yang dilakukan oleh peneliti adalah pada siswa yang berperilaku merokok. Perilaku merokok pada remaja umumnya semakin meningkat sesuai dengan tahap perkembangan yang ditandai denagn meningkatnya frekuensi dan intensitas merokok, dan sering mengakibatkan mereka mengalami ketergantungan nikotin. Nikotin dapat menimbulkan ketagihan, baik pada perokok aktif maupun perokok pasif. Nikotin merupakan alkaloid yang bersifat stimulant. Konseling dengan teknik ini juga akan mengarahkan kepada perbaikan fungsi berfikir, merasa dan bertindak dengan menekankan otak sebagai pusat penganalisa, pengambil keputusan, bertanya, bertindak serta memutuskan kembali. estrukturisasi kognitif itu juga bagian suatu proses atau kegiatan belajar untuk menyangkal adanya kesalahan dalam berfikir dengan tujuan untuk menggantikan pikiran seseorang yang tidak rasional, keyakinan kontra faktual yang akurat dan dominan. Tujuan dari teknik ini salah satunya yaitu mengurangi fikiran-fikiran negatif, mengubah proses berfikir disfungsional serta mengubah keyakinan irasional menjadi rasional.

Adapun tujuan dari Teknik restruturisasi kognitif yaitu menurut Rika Damayanti tujuan dari Implementasi teknik restrukturisasi kognitif yaitu untuk membangun pola pikir yang lebih adaftif atau sesuai (Damayanti \& Nurjannah, 2016). Sedangkan menurut Krisnayana tujuan dari konseling kognitif adalah mengubah pikiran yang belum teramati dan negatif. Konseling kognitif berfokus pada distorsi kognitif yang berlebihan seperti pola pikir, prediksi negatif, generalisasi berlebihan, melabeli diri sendiri, mengkriktik diri sendiri dan personalisasi (T.A, Antari, \& Dantes, 2014). Berdasarkan pendapat ahli di atas dapat disimpulkan bahwa tujuan dari teknik restruturisasi kognitif adalah untuk membangun pola pikir yang lebih adaptif atau sesuai, pikiran yang belum teramati dan negatif. Diane E. Papalia, Ruth Duskin Feldman mengatakan bahwa proses kognitif remaja terikat pada konten khusus atau keterampilan khusus atau apa yang anak pikirkan begitu juga dengan konteks permasalahan dan macammacam informasi serta pikiran terkait pentingnya pertimbangan budaya (E, Papalia, \& Feldman, 2014).

Mochamad Nursalim mengatakan Teknik restrukturisasi kognitif ini sendiri, dalam proses konseling bisa dilakukan secara individual dan secara kelompok (Nursalim, 2013), dalam hal ini peneliti menggunakan layanan konseling individual dimana konseling individual ini menurut Hellen, konseling individual yaitu layanan bimbingan dan konseling yang memungkinkan klien atau konseli mendapatkan layanan langsung tatap muka (secara 
perorangan) dengan guru pembimbing atau konselor dalam rangka pembahasan pengentasan masalah pribadi yang di derita konseli (Hellen, 2005). Prayitno juga berpendapat bahwa konseling individual adalah proses pemberian bantuan yang dialakukan melalui wawancara konseling oleh seorang ahli (konselor) kepada individu yang sedang mengalami sesuatu masalah (klien) yang bermuara pada teratasinya masalah yang dihadapi klien (Prayitno \& Amti, 1994). Jadi, dapat di simpulkan bahwa permasalahan perilaku merokok dengan teknik restrukturisasi lebih efektif menggunakan layanan konseling individual.

Berdasarkan observasi awal yang dilakukan penulis pada hari Rabu tanggal 8 Mei 2019 didapatkan adanya siswa yang ikut-ikutan untuk merokok, karena dikasih rokok oleh temannya, dan teman-temannya bilang kalau tidak merokok tidak gaul dan tidak keren. Kemudian didapatkan hasil bahwa ternyata siswa yang baru mencoba untuk merokok tersebut dalam beberapa hal sama dengan siswa yang sudah menjadi perokok aktif yaitu nafasnya bau, seragam sekolah yang dipakai juga bau asap rokok.

Berdasarkan wawancara dengan guru BK pada hari Kamis tanggal 9 Mei 2019 di dapatkan bahwa merokok di sekolah ini merupakan hal yang patut untuk di perhatikan, karna hampir sebagian siswa di SMA N 1 Batipuh merupakan perokok aktif, dan sebagian lagi masih mencoba-coba dan hanya ikut-ikutan teman-temannya. Hal ini dilihat dari siswa tersebut hanya merokok jika sudah berkumpul bersama teman-temannya, bahkan siswa tersebut pun tidak memiliki rokok sama sekali dan siswa tersebut diberi oleh teman-temannya rokok. Bahkan siswa yang baru mencoba-coba tersebut ada juga yang meminta izin keluar pada saat jam pelajaran dan pergantian jam, dan ternyata siswa tersebut menyusul temantemannya yang menjadi perokok aktif pergi ke warung untuk merokok, begitu yang terjadi setiap hari baik itu pada saat ujian pun siswa tersebut tetap izin untuk pergi merokok bersama teman-temannya yang lain, siswa tersebut juga tidak segan untuk merokok di warung tepi jalan dekat sekolah, semua orang yang lewat bisa melihatnya, dan siswa yang mencoba-coba rokok itu masih menggunakan seragam sekolah.

Hal yang dilakukan guru bimbingan dan konseling ketika melihat siswa di SMAN 1 Batipuh merokok memakai seragam sekolah atau kedapatan membawa rokok ke dalam kelas adalah memanggil siswa tersebut ke ruangan untuk diajak konseling individu agar siswa tersebut secara bebas mengemukakan hal yang dirasakannya terutama penyebab siswa tersebut ikut-ikutan merokok, serta disini guru bimbingan dan konseling bisa memberikan sedikit arahan atau memberikan informasi lewat vidio bahaya-bahaya rokok bagi kesehatan dan banyaknya dampak negatif yang akan muncul ketika kita merokok, bahkan dapat mengganggu proses pembelajaran dan mengakibatkan hasil belajar yang rendah. Salah satu cara yang biasa dilakukan untuk mengubah cara fikir siswa terkait rokok yaitu menggunakan pendekatan restrukturisasi kognitif, dimana dengan menata kembali pikiran-pikiran yang sebelumnya negatif mengubahnya kepada pikiran yang positif.

\section{METODE}

Penelitian ini adalah penelitian eksperimen, dengan jenisnya penelitian Pra-eksperimen. Jenis ini pada prinsipnya tidak dapat mengontrol validitas internal dan eksternal secara utuh, karena hanya satu kelompok yang diteliti satu kali atau kalau menggunakan dua kelompok itu tidak disamakan terlebih dahulu. Berdasarkan permasalahan di atas, model penelitian yang digunakan the one group pre test - post test design, dimana menurut A. Muri Yusuf jenis penelitian ekperimen the one group pre test-post test design adalah memberikan perlakuan terhadap sutu kelompok (tidak ada kelompok kontrol) dengan melihat perbedaan pre test dan post test sebagai hasil perlakuan (Yusuf, 2014). 
Pengumpulan data dilakukan untuk memperoleh informasi yang dibutuhkan dalam rangka mencapai tujuan penelitian, untuk mengumpulkan data dari sampel penelitian dilakukan dengan metode tertentu sesuai dengan tujuannya. Adapun metode yang digunakan adalah skala. Adapun tahapan-tahapan pengolahan data yang digunakan adalah sebagai berikut : Seleksi data, menyisihkan data-data yang terkait dengan masalah yang diteliti, Coding, mengklasifikan jawaban-jawaban dari para responden, Menghitung tiap item serta skor item secara total, Tabulasi data, yaitu memasukkan data yang diperoleh kedalam table, Mencari rata-rata (Mean) yang signifikan antara pengukuran pretest dari kelompok eksperimen dan kelompok kontrol. Dalam penelitian ini pengujian hipotesis pretest dan posttest data yang telah terkumpul dianalisa dengan uji statistik non parametrik menggunakan Wilcoxon rank test untuk menguji hipotesis pretest dan posttest eksperimen.

\section{HASIL DAN PEMBAHASAN}

Penelitian ini dilakukan di SMA N 1 Batipuh, pelaksanaan kegiatan penelitian ini yaitu berupa pemberian layanan konseling individual menggunakan teknik restrukturisasi kognitif untuk mereduksi perilaku merokok siswa. Peneliti menggunakan instrument yaitu angket.

\section{Deskripsi Data Pre-Test}

Bagian ini memaparkan pendeskripsian data dari instrumen yang digunakan, berikut ini data yang telah diperoleh:

Tabel 1. Data Pretest Perilaku Merokok

\begin{tabular}{cccc}
\hline No & Kode/Inisial & Skor & Keterangan \\
\hline 1 & AM & 86 & Sedang \\
2 & AA & 72 & Sedang \\
3 & TA & 77 & Sedang \\
4 & MA & 75 & Sedang \\
5 & RP & 82 & Sedang \\
& Rata-rata & 78.40 & Sedang \\
\hline
\end{tabular}

Berdasarkan tabel di atas dapat dipahami bahwa jumlah sampel sebelum diberikan perlakuan tingkat perilaku merokok siswa kelas XI IPA 1 dan siswa XI IPA 3, ke 5 orang siswa tersebut mengalami perilaku merokok sedang. Berdasarkan tabel di atas pula dapat disimpulkan bahwa rata-rata skor pretest yaitu sebelum diberikan perlakuan layanan konseling individual menggunakan teknik restrukturisasi kognitif, tingkat perilaku merokok siswa tergolong ke dalam kategori sedang dengan skor rata-rata 78,40. Artinya sampel yang diberikan pretest sebanyak 5 orang mengalami perilaku merokok.

\section{Deskripsi Data Post-Test}

Tabel 2. Data Posttest Perilaku Merokok

\begin{tabular}{cccc}
\hline No & Kode/Inisial & Skor & Keterangan \\
\hline 1 & AM & 65 & Rendah \\
2 & AA & 66 & Rendah \\
3 & TA & 69 & Rendah \\
4 & MA & 72 & Sedang \\
5 & RP & 74 & Sedang \\
& Rata-Rata & 69.20 & Rendah \\
\hline
\end{tabular}

Berdasarkan tabel di atas dapat dipahami bahwa setelah diberikan perlakuan yaitu layanan konseling individual menggunakan teknik restruktutisasi kognitif jadi menurun, ini 
terlihat dari kategori skor rendah ada 3 orang dan skor sedang ada 2 orang. Berdasarkan tabel di atas pula, dapat disimpulkan bahwa rata-rata skor posttest yaitu setelah diberikan perlakuan layanan konseling individual menggunakan teknik restrukturiasi kognitif tergolong ke dalam kategori rendah dengan skor rata-rata 69,20. Artinya sampel yang diberikan posttest sebanyak 5 orang sudah berkurang perilaku merokoknya.

\section{Uji Homogenitas}

Uji homogenitas dilakukan untuk melihat kesamaan data, atau disebut juga dengan uji varian.

Tabel 3. Hasil Uji Homogenitas

\begin{tabular}{llllll}
\hline & Sum of Squares & Df & Mean Square & F & Sig. \\
\hline Between Groups & 211.600 & 1 & 211.600 & 9.200 & .016 \\
Within Groups & 184.000 & 8 & 23.000 & & \\
Total & 395.600 & 9 & & & \\
\hline
\end{tabular}

\section{Uji Hipotesis}

Data yang terkumpul dianalisa menggunakan uji Wilcoxon. Tujuan uji Wilcoxon adalah untuk mengetahui apakah hipotesis yang diajukan diterima atau ditolak. Untuk melihat data yang digunakan berdistribusi normal, maka metode yang digunakan metode non parametrik. Uji Wilcoxon pada penelitian ini menggunakan bantuan IBM SPSS versi 20. Ketentuan yang berlaku dalam uji Wilcoxon adalah jika Sig $>\alpha(0,05)$ maka Ha ditolak dan jika Sig $<\alpha(0,05)$ maka Ha diterima.

Tabel 4. Hasil Uji Wilcoxon Pretest dan Posttest Kelompok Eksperimen

\begin{tabular}{cc} 
& Posttest - Pretest \\
\cline { 2 - 2 } Asymp. Sig. (2-tailed) & $-2.032^{\mathrm{b}}$ \\
\hline
\end{tabular}

Berdasarkan hasil perhitungan uji Wilcoxon diperoleh nilai signifikansi $p$-value sebesar 0,042 . Berdasarkan ketentuan yang berlaku, diketahui hasil uji Wilcoxon Sig. $p$-value $0,042<$ $\alpha(\alpha=0,05)$ yang artinya Ha diterima. Berdasarkan hasil uji Wilcoxon diatas maka dapat disimpulkan bahwa Ha diterima dan Ho di tolak dengan hipotesis yang di ajuakan, Tingkat periaku merokok siswa berkurang setelah diberikan perlakuan yaitu layanan konseling individual melalui teknik restrukturisasi kognitif untuk mereduksi perilaku merokok siswa.

Merokok sering dimulai dari Sekolah Menengah, merokok merupakan kegiatan yang meluas dalam berbagai kegiatan sosial dan juga daerah-daerah terlarang, seperti di halaman sekolah, remaja merasa dirinya harus lebih banyak menyesuaikan diri dengan norma-norma orang dewasa atau penguasa lembaga bila memang ingin dianggap hampir dewasa. Sering terlihat dijalan atau tempat yang biasa dijadikan sebagai tempat "berkumpul" anak-anak tingkat sekolah menengah atas, kebanyakan pada siswa laki-laki merokok merupakan kegiatan sosialnya. Menurut mereka merokok merupakan lambang pergaulan bagi mereka. Hampir semua orang mulai merokok dengan alasan yang sedikit sekali kaitannya dengan kenikmatan. Dalam pikiran remaja rokok lambang kedewasaan. Sebagai seorang remaja mereka melakukan berbagai cara untuk terlihat dewasa (Prasetya, 2017). Remaja ingin mencoba melakukan merokok, apa yang sering dilakukan oleh orang dewasa dengan sembunyi-sembunyi remaja merokok karena mereka melihat orang dewasa merokok. 
Pada masa remaja ada suatu yang lain yang sama pentingnya dengan kedewasaan, yakni solidaritas kelompok, dan melakukan apa yang dilakukan oleh kelompok. Apabila dalam suatu kelompok remaja telah melakukan kegiatan merokok maka individu remaja harus melakukannya. Individu remaja tersebut mulai merokok karena individu dalam kelompok remaja tersebut dianggap sebagai orang asing, bukan karena individu tersebut menyukai rokok. Intinya bagi remaja merokok merupakan kematangan walaupun sebenarnya sangat merugikan dirinya (Hurlock, 1980).

Untuk mengatasi timbulnya masalah perilaku merokok di atas, maka konseling individual dengan teknik restrukturisasi kognitif dapat mereduksi perilaku merokok siswa. Cognitive Restrcturing menggunakan asumsi bahwa respons-respons perilaku dan emosional yang tidak adaptif dipengaruhi oleh keyakinan, sikap, dan persepsi (kognisi) konseli (Nursalim, 2013). Untuk mengatasi perilaku merokok ini pendekatan konseling individual menggunakan teknik khusus yaitu teknik restrukturisasi kognitif. teknik restrukturisasi kognitif adalah membentuk ulang pola-pola kognitif, asumsi-asumsi, keyakinan-keyakinan, dan penilaianpenilaian yang irasional, merusak, dan mengalahkan diri sendiri. Terapis disini mencoba untuk mengubah distorsi-distorsi kognitif tersebut dengan menguji ulang keyakinan klien dengan berbagai teknik persuasi verbal, metode pertanyaan Socrates, atau menggunakan model hipotesis (Safaria, 2004).

Teknik restrukturisasi kogntif dapat dilakukan dalam konseling individual, agar teknik restrukturisasi kogntif ini dapat dilaksanakan secara efektif, karena konseling individual layanan langsung tatap muka (secara perorangan) dengan guru pembimbing atau konselor dalam rangka pembahasan pengentasan masalah pribadi yang di derita klien (Hellen, 2005). Konseling individual adalah proses pemberian bantuan yang dialakukan melalui wawancara konseling oleh seorang ahli (konselor) kepada individu yang sedang mengalami sesuatu masalah (klien) yang bermuara pada teratasinya masalah yang dihadapi klien (Prayitno \& Amti, 1994).

Hasil pengolahan data diketahui bahwa pretest dengan jumlah sampel 5 orang setelah diberikan perlakuan yaitu layanan konseling individual menggunakan teknik restukturisasi kognitif untuk mereduksi perilaku merokok siswa tergolong ke dalam kategori sedang dengan jumlah skor 392 dengan rata-rata 78,40. Hasil pengolahan data diketahui bahwa posttest dengan jumlah sampel 5 orang setelah diberikan perlakuan yaitu layanan konseling individual menggunakan teknik restukturisasi kognitif untuk mereduksi perilaku merokok siswa tergolong ke dalam kategori sedang dengan jumlah skor 346 dengan rata-rata 69,20. Artinya sampel yang diberikan posttest sebanyak 5 orang sudah mengurangi perilaku merokok. Perubahan pada hasil posttest setelah diberikan perlakuan yaitu yaitu layanan konseling individual menggunakan konseling individual dengan teknik restrukturisasi kognitif menunjukkan bahwa layanan ini dapat mengurangi perilaku merokok siswa. Hal ini juga sesuai dengan tujuan mengubah pikiran, pola pikir, prediksi negatif, generalisasi berlebihan, melabeli diri sendiri, mengkriktik diri sendiri dan personalisasi (T.A, Antari, \& Nyoman Dantes, 2014).

Dari perbandingan hasil pretest dan posttest dapat terlihat adanya penurunan rata-rata yang kemudian di analisis menggunakan uji Wilcoxon. Hipotesis yang di ajukan diterima dan dapat dikatakan bahwa layanan konseling individual menggunakan teknik restrukturisasi kognitif efektif dalam mengatasi perilaku merokok siswa. Uji hipotesis pretest dan posttest, apabila dikonversikan kenilai $Z$ maka besarnya $-2,032$, nilai sig ataup-value sebesar $0,042<0,05$. Apabila nilaip-value $<0,05$ maka Ha diterima dan Ho ditolak. Artinya ada perbedaan tingkat perilaku merokok sebelum dan sesudah diberikan perlakuan atau layanan konseling individual menggunakan teknik restrukturisasi kognitif. Hasil pengujian hipotesis untuk pretest dan posttest dapat disimpulkan bahwa Ha diterima dan Ho ditolak, sehingga 
tingkat perilaku merokok berkurang setelah diberikan perlakuan yaitu konseling individual dengan teknik restruktutisasi kognitif.

Tujuan yang ingin dicapai dalam penelitian ini adalah untuk mengetahui efektifitas layanan konseling individual menggunakan teknik restrukturisasi kognitif untuk mereduksi perilaku merokok telah tercapai. Karena dalam penelitian ini telah diperoleh hasil bahwa konseling individual menggunakan teknik restrukturisasi kognitif untuk mereduksi perilaku merokok siswa.Adapun treatment yang diberikan untuk mengurangi perilaku merokok ini dilakukan sebanyak masing-masing 5 kali dan diberikan posttest sebagai pengukuran. Pada penelitian ini peneliti memberikan konseling individual menggunakan teknik restrukturisasi kognitif untuk mereduksi perilaku merokok siswa terkait dengan permasalahan perilaku merokok

\section{KESIMPULAN}

Sebelum diberikan layanan konseling individual menggunakan teknik restrukturisasi kognitif hasil pretest dengan jumlah sampel 5 orang meannya adalah 78,40 mediannya adalah 77,00 yang mana ini adalah titik tengah data yang telah diurutkan. Kemudian variannya adalah 31,300 yaitu varians data yang di dapat dari kelipatan standar deviasi, sedangkan nilai tertinggi dalam kelompok ini adalah 86 nilai terendah 72 standar deviasi 5, 595 adalah ukuran penyebaran data dari rata-ratanya dan standar erornya adalah 2,502 yang mana ini adalah kesalahan standar untuk populasi yang diperkirakan dari sampel dengan menggunakan ukuran rata-rata. Setelah diberikan layanan individual menggunakan teknik restrukturisasi kognitif hasil posstest dengan jumlah sampel 5 orang, meannya adalah 69,20 mediannya adalah 69,00 yang mana ini adalah titik tengah data yang telah diurutkan, kemudian variannya adalah 14,700 yaitu varians data yang di dapat dari kelipatan standar deviasi, sedangkan nilai tertinggi dalam kelompok ini adalah 74 nilai terendah 65 standar deviasi 3,834 adalah ukuran penyebaran data dari rata-ratanya dan standar errornya adalah 1,715 yang mana ini adalah kesalahan standar untuk populasi yang diperkirakan dari sampel dengan menggunakan ukuran rata-rata. Perbedaan nilai pretest dan posttest diketahui dari hasil nilai uji $Z$ (Wilcoxon) menunjukkan perbedaan antara nilai pretest dan posttest. Dari hasil perhitungan uji Wilcoxon diperoleh nilai signifikansi $p$-value sebesar $-2,032$. Berdasarkan ketentuan yang berlaku, diketahui hasil uji Wilcoxon Sig $p$-value sebesar $0,042<\alpha(\alpha=0,05)$ yang artinya Ha diterima dan Ho ditolak. Dari hasil perhitungan uji Wilcoxon dapat disimpulkan bahwa konseling individual menggunakan teknik restrukturisasi kognitif dapat mengurangi perilaku merokok siswa.

\section{REFERENSI}

Antara, I. N. K. T., Antari, N. N. M., \& Dantes, N. (2014). Penerapan Konseling Kognitif dengan Teknik Restrukturisasi Kognitif untuk Meningkatkan Resiliensi Siswa Kelas XI IPA 1 SMA Negeri 3 Singaraja. Jurnal IImiah Bimbingan Konseling Undiksha, 2(1).

Anugroho, D. Wulandari, A., \& Westriningsih. (2011). Cara Jitu Mengatasi Impotensi. Yogyakarta: Andi.

Arikunto, S. (2000). Manajemen Penelitian. Jakarta: Rineka Cipta.

Arikunto, S. (2013). Manajemen Penelitian. Jakarta: Rineka Cipta.

Asmani, J. M. (2012). Kiat Mengatasi Kenakalam Remaja di Sekolah. Yogyakarta: Buku biru. 
Basyir, A. U. (2005). Mengapa Ragu Tinggalkan Rokok?, Jakarta: Pustaka At-Tazkia.

Bungin, B. (2006). Metodologi Penelitian Kuantitatif. Jakarta: Putra Grafika.

Corey, G. (2005). Teori dan Praktek Konseling dan Psikoterapi. (Alih Bahasa: E. Koeswara). Bandung : Rafika Aditama.

Damayanti, R., \& Nurjannah, P. A. (2016). Pengaruh Konseling Kognitif Perilaku dengan Teknik Restrukturisasi Kognitif Terhadap Harga Diri Peserta Didik Kelas VIII Di MTs N 2 Bandar Lampung. KONSELI: Jurnal Bimbingan dan Konseling (E-Journal), 3(2), 219 232.

Departemen Pendidikan Nasional. (2003). KBBI Cet ke 3. Jakarta: Balai Pustaka.

Depertemen Agama. (2004). Al-quran dan Terjemahan. Surabaya: Mekar Surabaya.

Efendi, M. (2017). STUDI MULTIKASUS: Epidemi Perilaku Merorok di Kalangan Remaja dan Implikasinya dalam Pendidikan. Edcomtech Jurnal Kajian Teknologi Pendidikan, 1(1), 69-82.

Erford, B. T., (2016). 40 Teknik yang harus diketahu isetiap konselor. Yogyakarta: Pustaka Pelajar.

Fatimah, E. (2006). Psikologi Perkembangan. Bandung: Pustaka Setia.

Harawi, D. (2006). Penyalah Gunaan dan Ketergantungan Napza. Jakarta: Fakultas Kedokteran Universitas Indonesia.

Hellen. (2005). Bimbingan dan Konseling. Jakarta: Quantum Teaching.

Hurlock, B. E. (1980). Psikologi Perkembangan: Suatu Perkembangan Sepanjang Rentang Kehidupan. Jakarta: Erlangga.

Ireel, A. M., Elita, Y., \& Mishbahuddin, A. (2018). Efektivitas layanan konseling kelompok teknik restrukturisasi kognitif untuk mereduksi kecemasan menghadapi ujian siswa smp di kota bengkulu. Consilia: Jurnal Ilmiah Bimbingan Dan Konseling, 1(2), 1-10.

Iswantir, I. (2017). Gagasan dan Pemikiran Serta Praksis Pendidikan Islam di Indonesia (Studi Pemikiran dan Praksis Pendidikan Islam Menurut Azyumardi Azra). Journal Educative: Journal of Educational Studies, 2(2), 165-177.

Kabo, P. (2008). Mengungkapkan Pengobatan Penyakit Jantung Koroner. Jakarta: Gramedia Pustaka Utama.

Komasari, D., \& Helmi, A. F. (2000). Faktor-faktor penyebab perilaku merokok pada remaja. Jurnal Psikologi, 27(1), 37-47.

Lumongga, D. N. (2016). Depresi: tinjauan psikologis. Kencana.

Nursalim, M. (2013). Strategi \&Interversi Konseling. Jakarta: Indeks.

Papalia, D. E., \& Feldman, R. D. (2014). Experience Human Delopment 12th. Jakarta: Salemmba Humanika.

Partodihardjo, S. (2006). Kenali narkoba \& musuhi penyalahgunaannya. ESENSI. 
Prayitno \& Amti, E. (1994). Dasar-Dasar Bimbingan dan Konseling. Jakarta: Rineka Cipta.

Price, D. (2007). Asma. Jakarta: Erlangga.

Rahmi, S. (2015). Pengaruh pendekatan perilaku kognitif terhadap tingkat penyesuaian diri siswa di kelas VII SMP Negeri 29 Makassar. Jurnal Psikologi Pendidikan \& Konseling Vol No.

Safaria, T. (2004). Terapi Kognitif-Periaku Untuk Anak. Yogyakarta: Graha IImu

Sarwono, J. (2006). Metode Penelitian Kuantitatif dan Kualitatif. Yogyakarta: Graha IImu.

Sesmiarni, Z. (2015). Membendung Radikalisme Dalam Dunia Pendidikan Melalui Pendekatan Brain Based Learning. Kalam, 9(2), 233-252.

Sochting, I. (2014). Cognitive behavioral group therapy: Challenges and opportunities. John Wiley \& Sons.

Sugiyono. (2016). Metode Penelitian Pendidikan: Pendekatan Kuantitatif, Kualitatif dan R\&D). Bandung: Alfabeta.

Suryabrata, S. (2012). Metode Penelitian. Jakarta: RajaGrafindo Persada.

Sutirna. (2013). Bimbingan dan Konseling. Yogyakarta: Andi.

Syam, N. W. (2014). Psikologi Sosial Sebagai Akar Ilmu Komunikasi. Bandung: Remaja Rosdakarya.

Taufik. (2009). Model-model Konseling. Padang: UNP Press.

Tohirin. (2011). Bimbingan dan Konseling di Sekolah dan Madrasah (Berbasis Integrasi). Jakarta : Raja Grafindo Persada.

Yusuf, A. M. (2014). Metodologi Penelitian (kuantitatif, kualitatif dan penelitian gabungan), Padang: UNP Press. 